\title{
Nitrogen and Bromide Co-Doped Hydroxyapatite Thin Films with Antimicrobial Properties
}

\author{
Simona Liliana Iconaru ${ }^{1}$ (), Carmen Steluta Ciobanu ${ }^{1}$, Daniela Predoi ${ }^{1, *}$, Mikael Motelica-Heino ${ }^{2}$, \\ Constantin Cătălin Negrilă ${ }^{1}$, Monica Luminita Badea ${ }^{1,3}$, Mihai Valentin Predoi ${ }^{4}$, \\ Carmen Mariana Chifiriuc $5,6,7,8, * \mathbb{D}$ and Marcela Popa ${ }^{5,6, *(1)}$
}

check for

updates

Citation: Iconaru, S.L.; Ciobanu, C.S.;

Predoi, D.; Motelica-Heino, M.;

Negrilă, C.C.; Badea, M.L.; Predoi,

M.V.; Chifiriuc, C.M.; Popa, M.

Nitrogen and Bromide Co-Doped Hydroxyapatite Thin Films with Antimicrobial Properties. Coatings 2021, 11, 1505. https://doi.org/ 10.3390/coatings11121505

Academic Editor: Enrico Sassoni

Received: 7 November 2021

Accepted: 30 November 2021

Published: 7 December 2021

Publisher's Note: MDPI stays neutral with regard to jurisdictional claims in published maps and institutional affiliations.

Copyright: (c) 2021 by the authors. Licensee MDPI, Basel, Switzerland. This article is an open access article distributed under the terms and conditions of the Creative Commons Attribution (CC BY) license (https:// creativecommons.org/licenses/by/ $4.0 /)$.
1 National Institute of Materials Physics, Atomistilor Street, No. 405A, P.O. Box MG 07, 077125 Magurele, Romania; simonaiconaru@gmail.com (S.L.I.); ciobanucs@gmail.com (C.S.C.); catalin.negrila@infim.ro (C.C.N.); badea.artemisia@gmail.com (M.L.B.)

2 Department of Civil Engineering and Environment, Université d'Orléans, ISTO, UMR 7327 CNRS, 1A Rue de la Férollerie, 45071 Orléans, France; mikael.motelica@univ-orleans.fr

3 Faculty of Horticulture, University of Agronomic Sciences and Veterinary Medicine, 59 Marasti Blvd., 011464 Bucharest, Romania

4 Department of Mechanics, University Politehnica of Bucharest, BN 002, 313 Splaiul Independentei, Sector 6, 060042 Bucharest, Romania; predoi@gmail.com

5 Life, Environmental and Earth Sciences Division, Research Institute of the University of Bucharest (ICUB), University of Bucharest, 060023 Bucharest, Romania

6 Microbiology Department, Faculty of Biology, University of Bucharest, 1-3 Portocalelor Lane, 77206 Bucharest, Romania

7 Academy of Romanian Scientists, 54 Spl. Independentei St., District 5, 50085 Bucharest, Romania

8 Biological Sciences Division, The Romanian Academy, 25, Calea Victoriei, Sector 1, District 1, 010071 Bucharest, Romania

* Correspondence: dpredoi@gmail.com (D.P.); carmen.chifiriuc@gmail.com (C.M.C.); bmarcela.popa@bio.unibuc.ro (M.P.)

Abstract: Hydroxyapatite $\left(\mathrm{Ca}_{10}\left(\mathrm{PO}_{4}\right)_{6}(\mathrm{OH})_{2}, \mathrm{HAp}\right)$, due to its high biocompatibility, is widely used as biomaterial. Doping with various ions of hydroxyapatite is performed to acquire properties as close as possible to the biological apatite present in bones and teeth. In this research the results of a study performed on thin films of hydroxyapatite co-doped with nitrogen and bromine (NBrHAp) are presented for the first time. The NBrHAp suspension was obtained by performing the adapted coprecipitation method using cetyltrimethylammonium bromide (CTAB). The thin layers of NBrHAp were obtained by spin-coating. The stability of the NBrHAp suspension was examined by ultrasound measurements. The thin layers obtained by the spin-coating method were examined by scanning electron microscopy (SEM), optical microscopy (OM), and metallographic microscopy (MM). The presence of nitrogen and bromine were highlighted by energy-dispersive $\mathrm{X}$-ray spectroscopy (EDS) and X-ray photoelectron spectroscopy (XPS) studies. Fourier transform infrared spectroscopy (FTIR) was used to highlight the chemical status of nitrogen and bromine. In addition, the powder obtained from the NBrHAp suspension was analyzed by XRD. Moreover, the in vitro antimicrobial activity of the NBrHAp suspensions and coatings was investigated using the reference microbial strains Staphylococcus aureus ATCC 25923, Escherichia coli ATCC 25922, and Candida albicans ATCC 10231. The results highlighted the successful obtainment of $\mathrm{N}$ and $\mathrm{Br}$ co-doped hydroxyapatite suspension for the first time by an adapted co-precipitation method. The obtained suspension was used to produce pure NBrHAp composite thin films with superior morphological properties. The NBrHAp suspensions and coatings exhibited in vitro antimicrobial activity against bacterial and fungal strains and revealed their good antimicrobial activity.

Keywords: nitrogen; bromide; hydroxyapatite; co-doped; thin film; antimicrobial properties 


\section{Introduction}

The research of novel materials for biomedical applications is currently in accelerated development due to the growing demand for biomaterials with new and well-defined physico-chemical and biological properties. Hydroxyapatite $\left(\mathrm{Ca}_{10}\left(\mathrm{PO}_{4}\right)_{6}(\mathrm{OH})_{2}, \mathrm{HAp}\right)$ is one of the most widely used biomaterials for various applications such as biomedical (implantology, bone filer, stomatology, drug delivery systems, etc.) [1,2] and industrial (water and soil remediation, fertilizer, catalysis, etc.) [3,4]. Usually, in the human body, the natural HAp structure can be found other chemical elements such as fluoride, magnesium, etc. Thanks to its special structure, synthetic HAp has a natural chemical affinity that allows it to be doped with different species of anion or cation either by substitution or interstitial [5]. Additionally, the superior biocompatibility, osteoconductivity, bioactivity and osteogenicity of Hap makes it suitable for application in the medical field [1,2].

Many conventional routes (physical or chemical) have been reported for the synthesis of HAp nanoparticles, such as solid-state method [6], mechanochemical route [7], chemical precipitation [8], hydrothermal method [9], sol-gel route [10], pyrolysis method [11], etc. Through these routes, materials with controllable properties can be developed. Conversely, deposition techniques of HAp thin films such as spin coating, magnetron sputtering, electrodeposition, etc., are intensively studied because they allow the creation of biocoatings with well-defined properties [12,13].

Recently, a new alternative to the use of common HAp coatings is represented by the fabrication of doped HAp coatings, with new biological, antimicrobial and biocompatible properties, depending on the nature of the substituents [13]. Nitrogen $(\mathrm{N})$ is an essential chemical element that can be found in the human body in biomolecules such as nucleic acids, amino acids, etc. [14]. A previous study conducted by R. Namiki et al. [5] showed that HAp doping with $\mathrm{N}$, by the nitrogen-doping method, leads to enhanced bioactivity. Further, there are only a few papers that report studies on the biological properties (including antimicrobial properties) of the bromine compounds $[4,15,16]$.

Bioactive glass doped with $5 \% \mathrm{CaBr}_{2}$ has shown a strong anti-biofilm effect against oral microbial strains, such as Actinomyces viscosus, Streptococcus mitis, Veillonella parvula, Streptococcus gordonii and Porphyromonas gingivalis [16]. Cetyltrimethylammonium bromide (CTAB) is a widely used antimicrobial cationic surfactant (including in hospitals), due to the high ability of its quaternary ammonium compounds (QAC) to interact and efficiently destroy various microbial strains, thus having a strong microbicidal effect [17,18]. Moreover, to date, CTAB has successfully been used in the functionalization of various materials as a surfactant [4,19-21].

$\mathrm{CTAB}$ is a class of aliphatic quaternary ammonium surfactant known as an effective antiseptic agent against bacteria and fungi, and is widely used in biological applications [22,23]. The antimicrobial activity of CTAB and QACs (quaternary ammonium compound) is attributed mainly to their positive charge which can create an attraction with the negative charge of the bacterial cell. In addition to the already known mechanism of action of QACs (such as, they could easily be adsorbed to and penetrate the cell wall, can cause disruptions to the cytoplasmic membrane of bacteria and the plasma membrane of yeast, and interact with the inside proteins and lipids leading to cell wall lysis), in addition, the CTAB antibacterial effect could be due to the induction of superoxide stress in bacteria $[18,24,25]$.

Given that the emergence of microbial resistance to classic antibiotics is a top ten public health problem at a global level, with important consequences on the quality of life of the patient and the costs of treating these resistant infections, it is imperative to find new antimicrobial agents that can be safely used for the treatment of multidrug-resistant infections. Two of the most widespread pathogens that are involved in post-implant infections are Gram-positive Staphylococcus aureus together with Gram-negative Escherichia coli bacterial species, in addition to Candida albicans fungal strains [26,27]. Usually, in these cases, infection treatment consists of either the administration of high antibiotic doses or implant removal via surgical intervention, often associated with the use of antimicrobial agents to support and enhance the efficacy of surgical procedures [26-28]. 
One of the main approaches towards preventing implant-associated infections is to develop biomaterials with high biocompatibility and antimicrobial activity. In this context, the development of new antimicrobial thin films based on co-doped nitrogen (N) and bromine $(\mathrm{Br})$ hydroxyapatite could be of real interest, because they could decrease the risk of infection and thus decrease the use of antibiotics in addition to the risk of implant failure. However, there are no previous studies on such materials. The results of this current study show, for the first time, the ability to successfully obtain $\mathrm{N}$ and $\mathrm{Br}$ co-doped hydroxyapatite suspension by an adapted co-precipitation method. The obtained suspension was used to produce pure NBrHAp composite thin films with superior morphological properties. The results of the in vitro antimicrobial activity of the NBrHAp suspensions and coatings against various microbial strains revealed their good antimicrobial activity. This study presents, for the first time, the fabrication and characterization of hydroxyapatite layers co-doped with nitrogen $(\mathrm{N})$ and bromine $(\mathrm{Br})$ ions obtained by the spin-coating method. The surface properties of the thin layers were studied by scanning electron microscopy (SEM), optical microscopy (OM), metallographic microscopy (MM), energy-dispersive X-ray spectroscopy (EDS), X-ray photoelectron spectroscopy (XPS) studies and Fourier transform infrared spectroscopy (FTIR). X-ray diffraction (XRD) studies of NBrHAp powder were also conducted. The in vitro antimicrobial activity of the NBrHAp suspensions and coatings was investigated on bacterial and fungal strains belonging to representative species for the etiology of implant associated infections.

\section{Materials and Methods}

\subsection{Sample Preparation}

The first step for obtaining the NBrHAp composite thin films, consisted of obtaining the NBrHAp suspension by the co-precipitation method [29]. To synthesize the NBrHAp suspension, ammonium dihydrogen phosphate $\left(\left(\mathrm{NH}_{4}\right)_{2} \mathrm{HPO}_{4}\right)$, calcium nitrate $\left(\mathrm{Ca}\left(\mathrm{NO}_{3}\right)_{2} \cdot 4 \mathrm{H}_{2} \mathrm{O}\right)$, cetyl trimethyl ammonium bromide $\left(\mathrm{CTAB},\left[\left(\mathrm{C}_{16} \mathrm{H}_{33}\right) \mathrm{N}\left(\mathrm{CH}_{3}\right)_{3}\right] \mathrm{Br}\right)$ and deionized water were used. The $\mathrm{Ca} / \mathrm{P}$ molar ratio was 1.67 . The $\mathrm{pH}$ was continuously adjusted to 10 with ammonia $\left(\mathrm{NH}_{3}\right)$. Solutions of $\left(\mathrm{NH}_{4}\right)_{2} \mathrm{HPO}_{4}$ and $\mathrm{Ca}\left(\mathrm{NO}_{3}\right)_{2} \cdot 4 \mathrm{H}_{2} \mathrm{O}$ were co-precipitated in a solution of $\left[\left(\mathrm{C}_{16} \mathrm{H}_{33}\right) \mathrm{N}\left(\mathrm{CH}_{3}\right)_{3}\right] \mathrm{Br}$ under continuous stirring for $2 \mathrm{~h}$. The precipitate was washed with deionized water. After washing, the precipitate was centrifuged and redispersed in the deionized water. The suspension was stirred for $12 \mathrm{~h}$ at $50{ }^{\circ} \mathrm{C}$. The resulting suspension was used to prepare the NBrHAp composite thin films.

The second step was to develop the NBrHAp composite thin films on glass substrate $(5 \mathrm{~mm} \times 5 \mathrm{~mm})$ by the spin-coating technique. The glass substrate was previously degreased with acetone and dried for $30 \mathrm{~min}$ at a temperature of $100{ }^{\circ} \mathrm{C}$ to remove any impurities from the surface. To obtain NBrHAp thin films by the spin-coating technique, $0.2 \mathrm{~mL}$ of suspension was spun at $2500 \mathrm{rpm}$ for $20 \mathrm{~s}$. The deposition procedure was repeated 3 times to finally have a sufficiently thick film. After each deposition, the films were dried at $40{ }^{\circ} \mathrm{C}$ for $20 \mathrm{~min}$. At the end, the obtained films were heat treated in an oven at $100{ }^{\circ} \mathrm{C}$ for $5 \mathrm{~h}$ (heating rate of $2^{\circ} \mathrm{C} / \mathrm{min}$ ). Images with the obtained NBrHAp samples are presented in Figure 1a,b.

\subsection{Characterization Methods}

The stability of the NBrHAp suspension was evaluated by ultrasonic studies [4,30]. The experimental setup is described in previous studies [30]. To perform the ultrasound measurements, $100 \mathrm{~mL}$ of NBrHAp suspension was stirred for $30 \mathrm{~min}$ at room temperature using a magnetic stirrer. Two coaxial ultrasonic transducers H5K (General-Electric, Krautkramer) of $5 \mathrm{MHz}$ central frequency held at a fixed distance, were immersed in the NBrHAp suspension as previously reported [31]. The ultrasonic pulses were sent through the NBrHAp suspension. The ultrasonic signals from the oscilloscope were recorded as digital files, at a very precise interval of $5.00 \mathrm{~s}$. Signal processing was based on a comparison with the properties of double distilled water (the most stable fluid) as a reference, under the same experimental conditions. 


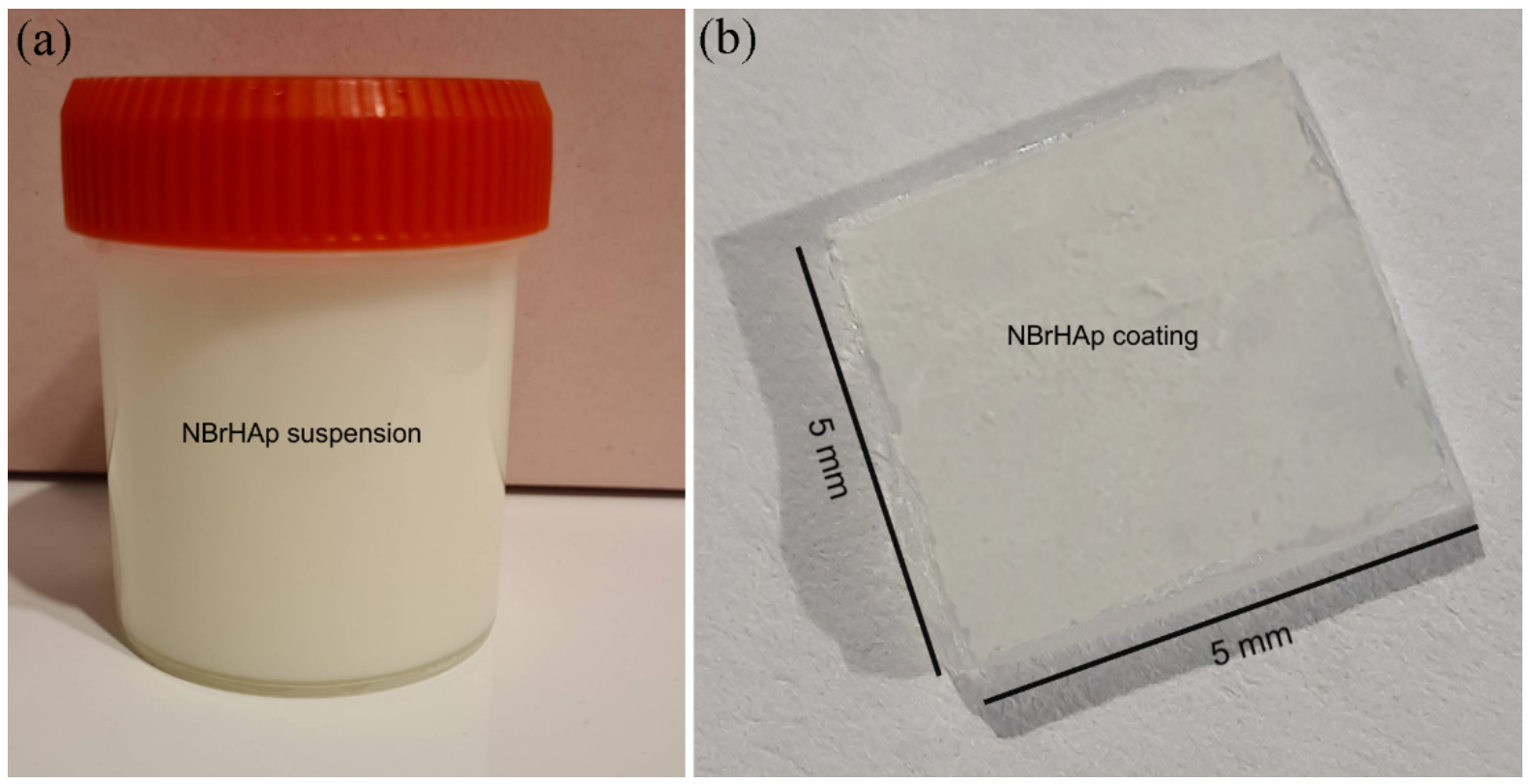

Figure 1. Images of the obtained NBrHAp suspension (a), and composite coatings (b).

An SZ-100 Nanoparticle Analyzer from Horiba-Jobin Yvon (Horiba, Ltd., Kyoto, Japan) was used to perform dynamic light scattering (DLS) and $\zeta$-potential analysis. The analysis was performed at $25 \pm 1{ }^{\circ} \mathrm{C}$. Before measurements of DLS and $\zeta$-potential, the obtained NBrHAp suspension was diluted 12 times. To register the scattered signals, diluted NBrHAp suspension was placed in a disposable cuvette. The sample was illuminated with a laser source that allowed the estimation of the particle diffusion velocity to determine the hydrodynamic diameter $(\mathrm{DH})$. Three determinations were recorded for each analysis.

The crystalline phases of the NBrHAp composite thin films were identified using X-ray diffraction using a D8 Advance diffractometer (Bruker, Karlsruhe, Germany) with $\mathrm{Cu}-\mathrm{K} \alpha(\lambda=1.5418 \AA)$ radiation and a high efficiency one-dimensional detector (Lynx Eye type) operated in integration mode. The diffractograms were acquired in the $2 \theta$ range of $20^{\circ}-70^{\circ}$, a scan rate of $1 \mathrm{~min}$ and sampling width of $0.02^{\circ}$. The acquisition time per step was $5 \mathrm{~s}$. The main (h kl) indices for the nanometer size of HAp were identified. The crystalline size, $\mathrm{D}(\mathrm{hkl})$, of the NBrHAp composite thin films was calculated from the XRD pattern using the Debye-Scherrer equation [32-34]:

$$
\mathrm{D}(\mathrm{hkl})=0.9 \lambda /(\mathrm{B} \cos \theta(\mathrm{hkl}))
$$

where $\mathrm{D}(\mathrm{hkl})$ is the crystallite size, $\lambda$ is the wavelength of the monochromatic $\mathrm{X}$-ray beam, $B$ is the full width at half maximum (FWHM) of the peak at the maximum intensity, and $\theta(\mathrm{hkl})$ is the peak diffraction angle that satisfies Bragg's law for the (h $\mathrm{kl}$ ) plane.

The presence of the NBrHAp composite thin film on the glass surface was evaluated by FTIR (Perkin Elmer SP-100, Waltham, MS, USA). FTIR spectra were recorded on transmittance mode at room temperature (in air) in the spectral domain $400-4000 \mathrm{~cm}^{-1}$ with a scan resolution of $4 \mathrm{~cm}^{-1}$ and 256 times scanning. The specimens were analyzed without any further preparation.

The chemical composition of the NBrHAp composite thin films was examined by X-ray photoelectron spectroscopy (XPS; SPECS GmbH, Berlin, Germany) with Al K $\alpha$ monochromatic radiation $(1486.6 \mathrm{eV})$. All recorded XPS spectra were analyzed using Spectral Data Processor v. 2.3 (SDP) software. The experimental conditions were in agreement with previous studies [35]. The vacuum in the analyzer chamber was $p \sim 3 \times 10^{-9}$ Torr. The $\mathrm{X}$-rays were emitted by an anti-cathode of $\mathrm{Al}, \mathrm{U}=12.5 \mathrm{kV}$, with filament emission current $\mathrm{I}=20 \mathrm{~mA}$. The XPS recorded spectrum involved an energy window $\mathrm{w}=20 \mathrm{eV}$ with the resolution $\mathrm{R}=20 \mathrm{eV}$, and with 400 recording channels. 
The NBrHAp composite thin films morphology was investigated by scanning electron microscopy (SEM) using a Hitachi S4500 apparatus (Hitachi, Tokyo, Japan). The SEM micrographs were recorded at 50,000 $\times$ magnification. Moreover, for the elemental composition evaluation, the SEM was equipped with an EDAX device (Ametek EDAX Inc Mahwah, NJ, USA). Before being placed in the microscope, the samples were attached to the specimen holder using a double-sided adhesive carbon tape. The 3D representation of the SEM micrographs was obtained with the help of ImageJ software (ImageJ 1.51j8, National Institutes of Health, Bethesda, MD, USA) [36].

The coatings surface morphology was evaluated by atomic force microscopy (AFM) with the aid of a NT-MDT NTEGRA Probe NanoLaboratory system (NT-MDT, Moscow, Russia) using non-contact mode. The topographies were recorded using a silicon NT-MDT NSG01 cantilever coated with a $35 \mathrm{~nm}$ gold layer and a tetrahedral tip. The 2D AFM micrographs were acquired on surface areas of $2.5 \times 2.5 \mu \mathrm{m}^{2}$. Analyses of the surface topographies and the 3D representation were performed with Gwyddion 2.55 software [37]. Furthermore, the roughness of the surface was also assessed by determining the $R_{R M S}$ from the AFM 2D topography.

More information regarding the surface morphology of the NBrHAp composite thin films was obtained by metallographic and optical microscopy. All the experiments were performed in agreement with the procedure previously reported [38,39] in ambient conditions. Both microscopy images (optical and metallographic) were obtained using a $10 \times$ magnification objective. The samples were investigated without any further preparation. The obtained 2D images and their 3D reconstruction were processed using Image J software (ImageJ 1.51j8, National Institutes of Health, Bethesda, MD, USA) [36].

\subsection{In Vitro Antimicrobial Assay}

The in vitro antimicrobial activity of the NBrHAp suspensions and coatings was investigated using the reference Staphylococcus aureus ATCC 25923, Escherichia coli ATCC 25922, and Candida albicans ATCC 10231 microbial strains. The antimicrobial experiments were performed as previously described in [40], using $0.5 \mathrm{McF}$ arland standard microbial cultures. The samples were exposed to $1.5 \mathrm{~mL}$ of microbial suspension with standardized density of $5 \times 10^{6} \mathrm{CFU} / \mathrm{mL}$ (colony forming units $/ \mathrm{mL}$ ), prepared in phosphate-buffered saline (PBS) and incubated for 24,48 and $72 \mathrm{~h}$, respectively. A free microbial culture was assessed at the same time intervals and was set as a positive control $(\mathrm{C}+)$. The values of the $\mathrm{CFU} / \mathrm{mL}$ were determined. The experiments were performed three times and the data was presented as mean \pm SD. The statistical analysis was performed using the ANOVA single factor test.

\section{Results}

The suspension was stirred for $15 \mathrm{~min}$ and poured in a cubic container having two coaxial ultrasonic transducers in the middle of opposite faces, distanced by $20 \mathrm{~mm}$. Ultrasonic signals produced by immersion transducers of $4 \mathrm{MHz}$ central frequency were generated and received every $5 \mathrm{~s}$. The first echo was the direct signal from the emitting to the receiving transducer. The reference signal was recorded for double distilled water in the same conditions and at the same temperature. Each recorded signal was processed, and the frequency spectra are shown in Figure 2a. The apparent maximum close to $4 \mathrm{MHz}$ was due to the central frequency of the two transducers. The highest values correspond to the reference liquid.

The suspension, tested every $5 \mathrm{~s}$, produced the lowest amplitudes at the beginning of the experiment and then progressively rose, as the nanoparticles tended to settle in the container. To eliminate the influence of the transducer, Figure $2 \mathrm{~b}$ was plotted with the relative difference of spectral amplitudes during the experiment. The relative narrow band of relative amplitudes indicated a good stability of the suspension and all curves being all almost horizontal, showed no interaction with the ultrasonic waves in the 2-8 MHz range. This lack of resonant frequencies proved that the nanoparticles in suspension were orders of magnitudes smaller than the shortest wavelength $(185 \mu \mathrm{m})$ used in the experiment. 

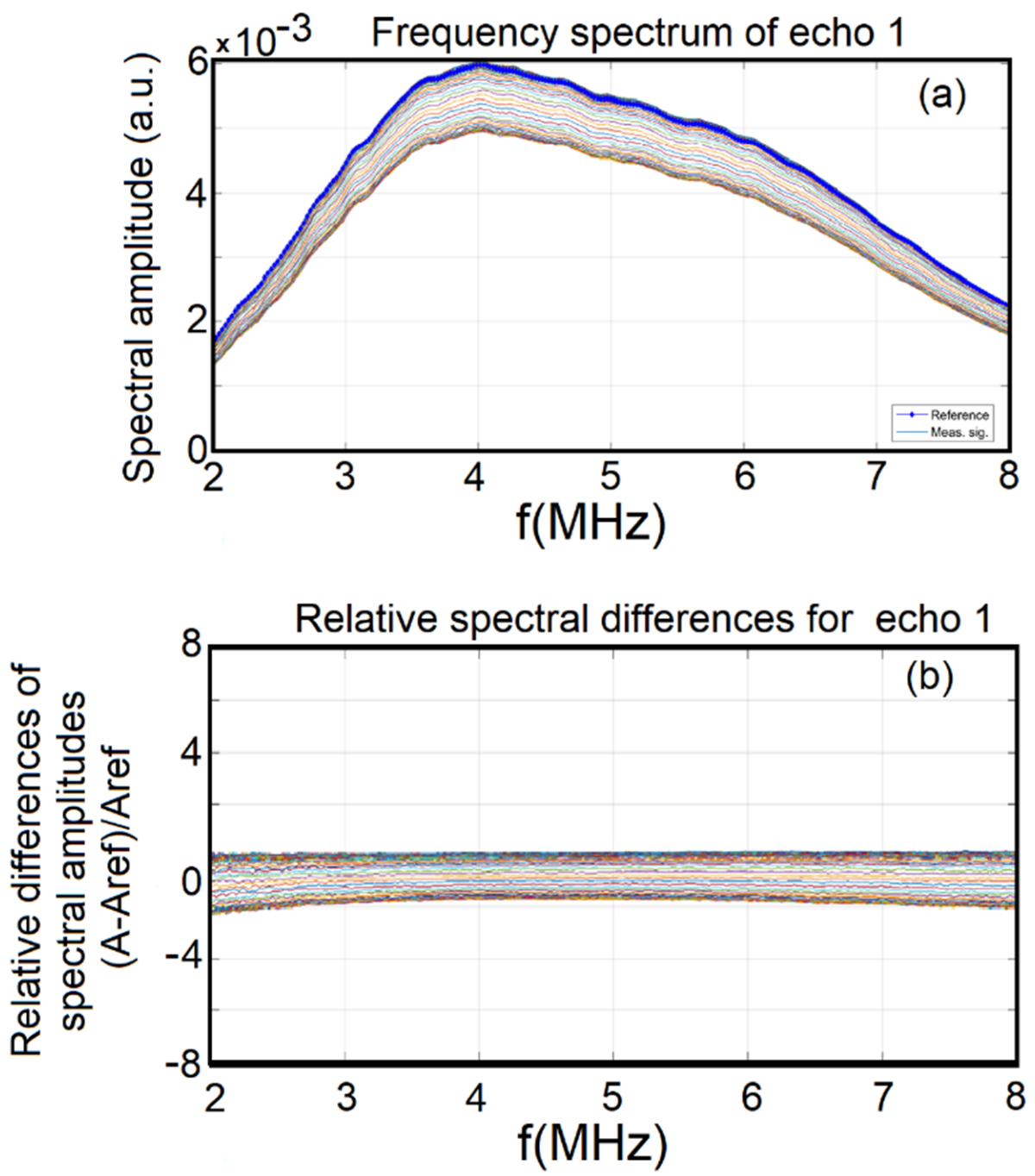

Figure 2. Each recorded signal processed and the frequency spectra (a), and the relative difference of spectral amplitudes during the experiment (b), of NBrHAp suspension.

The measurements of the $\zeta$-potential, together with the ultrasonic measurements, provided information on the stability of the NBrHAp suspension. The $\zeta$-potential is one of the important parameters that provide information about the stability of colloidal dispersions. The disadvantage of this technique is that the analysis cannot be performed on the stable suspension that was obtained. To determine the potential $\zeta$ of a stable suspension, the suspension needs to be diluted (the obtained stable NBrHAp suspension was diluted 12 times in this case). The value of the potential $\zeta$ determined for the NBrHAp suspension was $-35.86 \mathrm{mV}$.

The Stokes-Einstein equation [41] was used to calculate the hydrodynamic diameter of NBrHAp suspension (diluted 12 times). The average hydrodynamic diameter $\left(\mathrm{D}_{\mathrm{HYD}}\right)$ of the NBrHAp suspension was $55.8 \pm 0.3 \mathrm{~nm}$. The hydrodynamic particle size of NBrHAp suspension calculated from the DLS technique which leads to a larger particle size calculated by XRD is given by the core of the particles, the adsorbed substances on their surface and the thickness of the electrical double layer that moves along with the particle [42].

Figure 3 shows the XRD patterns of obtained NBrHAp composite powders resulting from the NBrHAp suspension after centrifugation $(12,000 \mathrm{rpm})$. The precipitate obtained by centrifugation was dried at $300^{\circ} \mathrm{C}$. The obtained powder was used for the XRD studies. The crystalline phases of the obtained NBrHAp composite powders were identified as HAp according to ICDD-PDF for HAp (\#09-0432). The crystalline phase of the obtained NBrHAp powders kept the single phase of pure HAp after $\mathrm{N}$ and $\mathrm{Br}$ co-doping process. 
The values obtained for the lattice parameters from the XRD measurements of NBrHAp powders (a-axis; $0.9425 \mathrm{~nm}$, c-axis; $0.6885 \mathrm{~nm}$ ) were higher than values of lattice parameters for pure HAp (a-axis; $0.9418 \mathrm{~nm}$, c-axis; $0.6884 \mathrm{~nm}$ ).

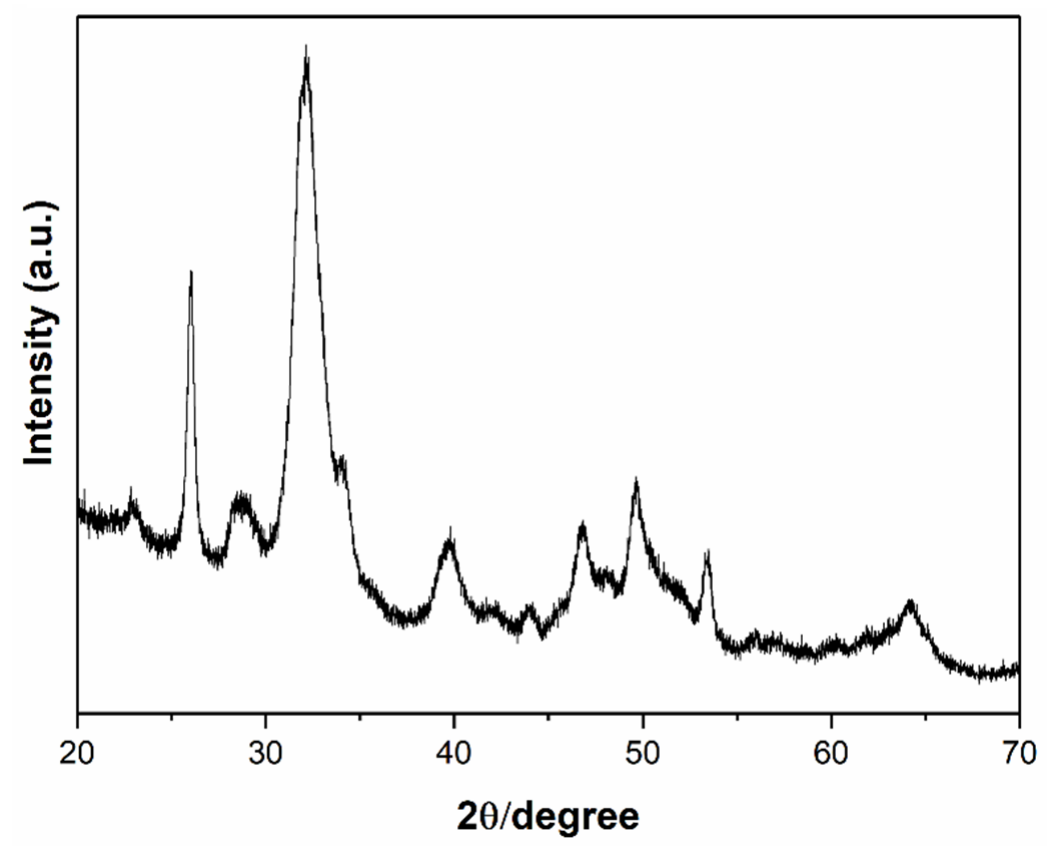

Figure 3. XRD patterns of obtained NBrHAp composite powders.

Moreover, the lattice parameters of c-axis in NBrHAp powders were close to that of pure HAp. The results obtained from XRD studies on the NBrHAp powder agreed with previously presented results [43]. The (002) reflection peak from the XRD pattern was used to calculate the NBrHAp composite crystallite size from the Debye-Scherrer equation $[32,33,44,45]$. The crystallite size was estimated to have a mean value of $18 \pm 2 \mathrm{~nm}$.

Fourier transform infrared (FTIR) spectroscopy allowed the identification of the functional groups present in the as-synthetized $\mathrm{N}$ and $\mathrm{Br}$ co-doped HAp suspension and thin films. The FTIR transmittance spectra obtained for both NBrHAp suspensions and thin layers are revealed in Figure 4.

The general FTIR spectra presented in Figure 4 revealed that all studied samples exhibited a similar profile. In the FTIR spectra of $\mathrm{N}$ and $\mathrm{Br}$ co-doped HAp suspension, the main peaks that are usually specific to the phosphate $\left[\mathrm{PO}_{4}{ }^{3-}\right]$ and hydroxyl $\left[\mathrm{OH}^{-}\right]$groups from the HAp structure were observed together with the specific peaks of $\delta\left(\mathrm{NH}_{4}{ }^{+}\right)$and $\mathrm{NH}_{4}{ }^{+}$from the CTAB structure $[4,46]$.

The specific peaks for $\left[\mathrm{PO}_{4}{ }^{3-}\right]$ from the HAp structure were found at around $473 \mathrm{~cm}^{-1}$ $\left(v_{3}\right), 562 \mathrm{~cm}^{-1}\left(v_{4}\right), 599 \mathrm{~cm}^{-1}\left(v_{4}\right), 961 \mathrm{~cm}^{-1}\left(v_{1}\right), 1021 \mathrm{~cm}^{-1}\left(v_{2}\right)$, and at around $1098 \mathrm{~cm}^{-1}$ $\left(v_{3}\right)[4,46]$. On the other hand, molecular bands typical for adsorbed water were noticed at about $1665 \mathrm{~cm}^{-1}$ and $3137 \mathrm{~cm}^{-1}[4,46]$. Additionally, the $\left[\mathrm{OH}^{-}\right]$functional groups from the HAp structure exhibited typical vibrational bands at $632 \mathrm{~cm}^{-1}$ and $3572 \mathrm{~cm}^{-1}[4,46]$. Moreover, the sharp peak from $1391 \mathrm{~cm}^{-1}$ was specific to the $\delta\left(\mathrm{NH}_{4}{ }^{+}\right)$vibration from the CTAB structure. The shoulder from $3012 \mathrm{~cm}^{-1}$ belonged to $\mathrm{NH}_{4}{ }^{+}$specific to the CTAB. No additional peaks were noticed in the obtained FTIR spectra. The results of the FTIR studies revealed that the main peaks present in the NBrHAp thin films were more intense compared with the peaks of NBrHAp suspension. Therefore, it was deduced that thermal treatment of the NBrHAp thin films deposited on the glass substrate at $100{ }^{\circ} \mathrm{C}$ degrees allowed layers to be obtained with an improved structure. Moreover, these results were in good agreement with those reported in other studies $[4,46]$. 


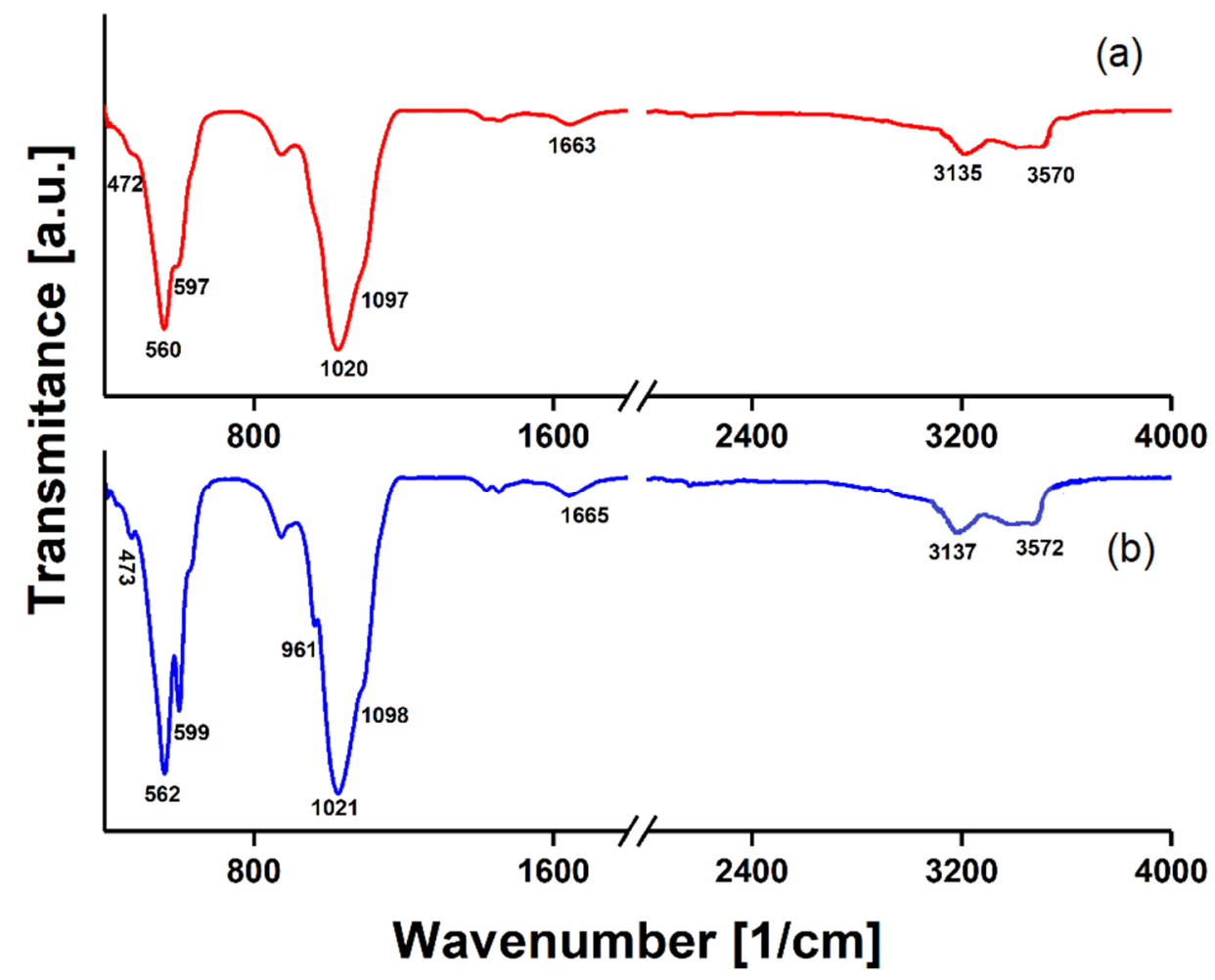

Figure 4. Typical FTIR spectra of N and Br co-doped HAp suspension (a), and NBrHAp thin films deposited on glass substrate (b).

Figure 5 presents the XPS spectra of $\mathrm{Br}$ and $\mathrm{N}$ co-doped HAp. The line of $\mathrm{C} 1 \mathrm{~s}$ from $284.8 \mathrm{eV}$ was used as reference. The XPS general spectrum exhibited the existence of calcium (Ca 2p), oxygen (O 1s), phosphorus (P 2p), nitrogen (N 1s), bromine (Br 3p; Br $3 \mathrm{~d})$ and carbon (C 1s) peaks. This result revealed the presence of $\mathrm{N}$ and $\mathrm{Br}$ ions in the NBrHAp composite thin films. The surface of the $\mathrm{N}$ and $\mathrm{Br}$ co-doped HAp ceramics thin films contained nitrogen and bromine after $\mathrm{N}$ and $\mathrm{Br}$ co-doping. The results of this study agreed with previous studies [5,47].

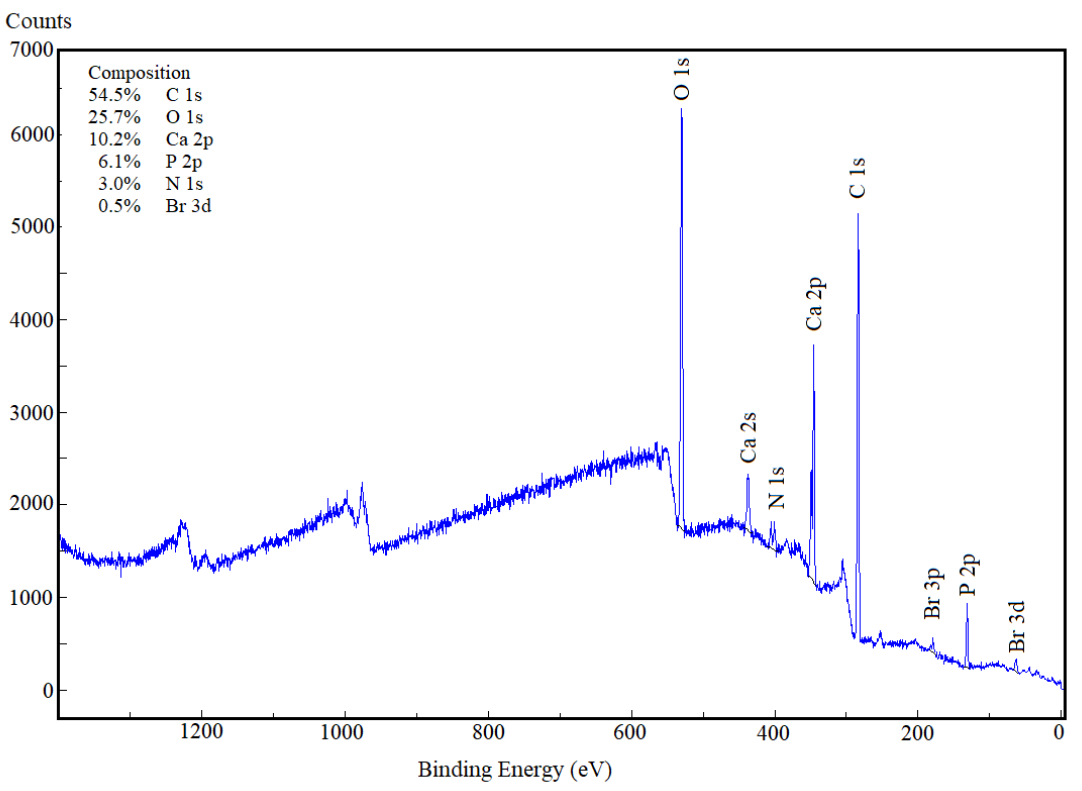

Figure 5. XPS general spectrum of $\mathrm{N}$ and $\mathrm{Br}$ co-doped HAp composite thin film. 
The scanning electron microscope equipped with an EDX device was used to evaluate the surface morphology and chemical composition of the obtained $\mathrm{N}$ and Br co-doped HAp composite thin film. The SEM images (2D and their 3D representation) along with EDS spectra obtained on the NBrHAp composite layers are depicted in Figure 6.
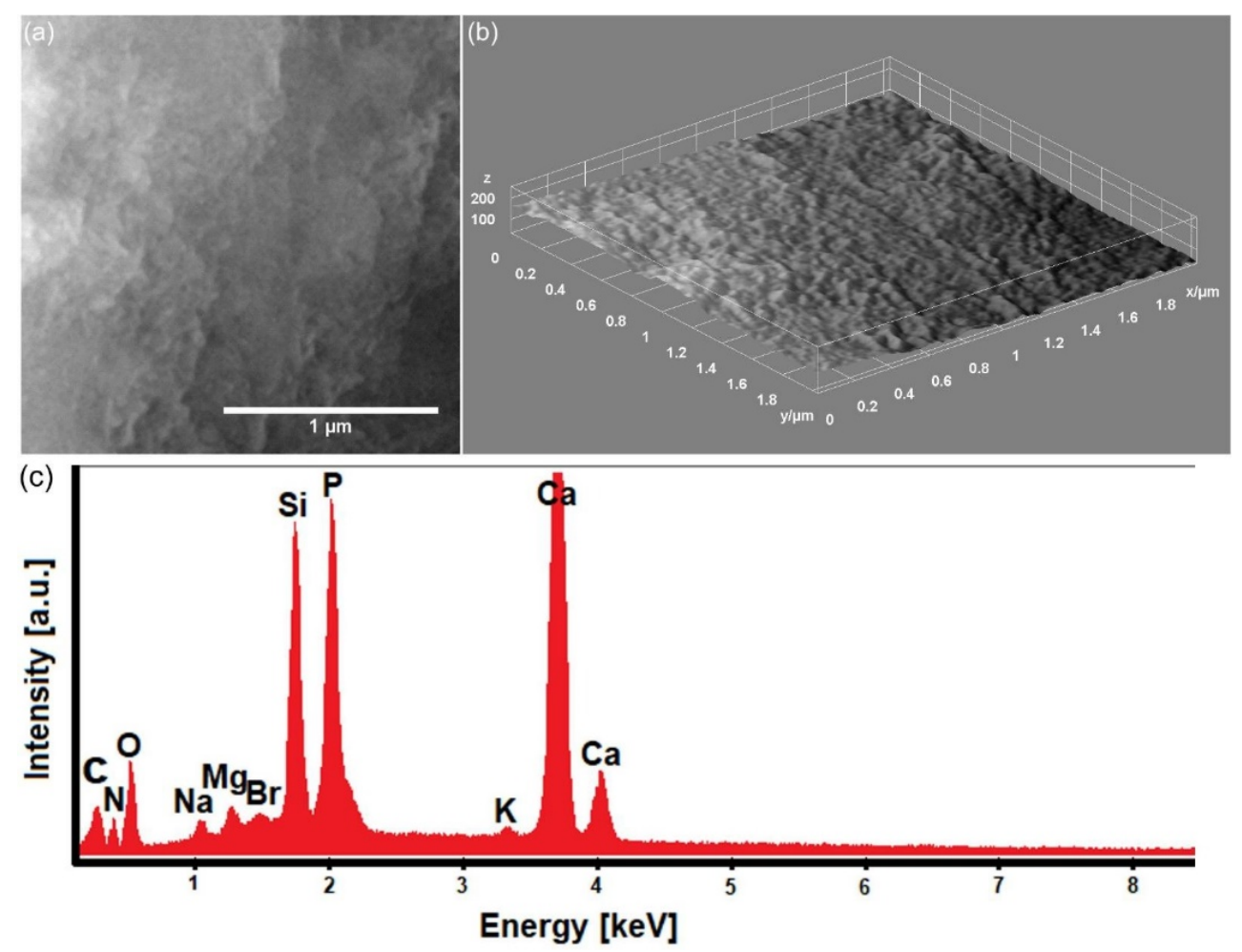

Figure 6. 2D (a) and 3D representation (b) of SEM images specific to NBrHAp composite layers. EDS spectra of $\mathrm{N}$ and $\mathrm{Br}$ co-doped HAp composite layers (c).

In the 2D SEM images, it was observed that the surface of the obtained layers was homogeneous and uniform. Moreover, the presence of a smooth surface with no surface defects was noticed. Therefore, these results show that the spin coating method is appropriate to obtain $\mathrm{N}$ and $\mathrm{Br}$ co-doped HAp composite layers with a good morphology.

Conversely, the presence in the EDS spectrum of chemical elements such as sodium $(\mathrm{Na})$, magnesium $(\mathrm{Mg})$, silicon $(\mathrm{Si})$ and potassium $(\mathrm{K})$ were due to the glass substrate on which the NBrHAp composite layers were deposited. Further, in the obtained EDS, the main chemical elements (calcium $(\mathrm{Ca})$, phosphorus $(\mathrm{P})$, oxygen $(\mathrm{O})$, carbon $(\mathrm{C})$, bromine $(\mathrm{Br})$ and nitrogen $(\mathrm{N})$ ) characteristic of NBrHAp layers were highlighted. The results of the EDS studies performed on the $\mathrm{N}$ and $\mathrm{Br}$ co-doped HAp obtained thin films agreed with those obtained from the XPS studies, thus confirming the purity of the analyzed samples.

The morphology of the NBrHAp coating's surface was evaluated by AFM studies. The data of AFM surface topography of NBrHAp coatings are depicted in Figure 7. The results of the AFM studies highlighted that the coatings presented the morphology of a uniformly deposited layer and did not show any evidence of cracks or fissures or any other unevenness. The 2D topography acquired on a surface of $2.5 \times 2.5 \mu \mathrm{m}^{2}$ depicted in Figure 7a also emphasized that the NBrHAp coatings were homogenous and evenly deposited on the surface of the glass substrate. Moreover, the 3D representation of the 2D topography of the NBrHAp surface coatings presented in Figure $7 \mathrm{~b}$ also suggested that the surface had the appearance of a uniform and homogenous deposited layer without any visible fissures and cracks. In addition, the roughness $\left(\mathrm{R}_{\mathrm{RMS}}\right)$ value for the NBrHAp coatings resulting from the AFM studies was $30.645 \mathrm{~nm}$. The results obtained by AFM studies were in good agreement with the results obtained by SEM visualization and by the two microscopy techniques employed in the study of these coatings. 

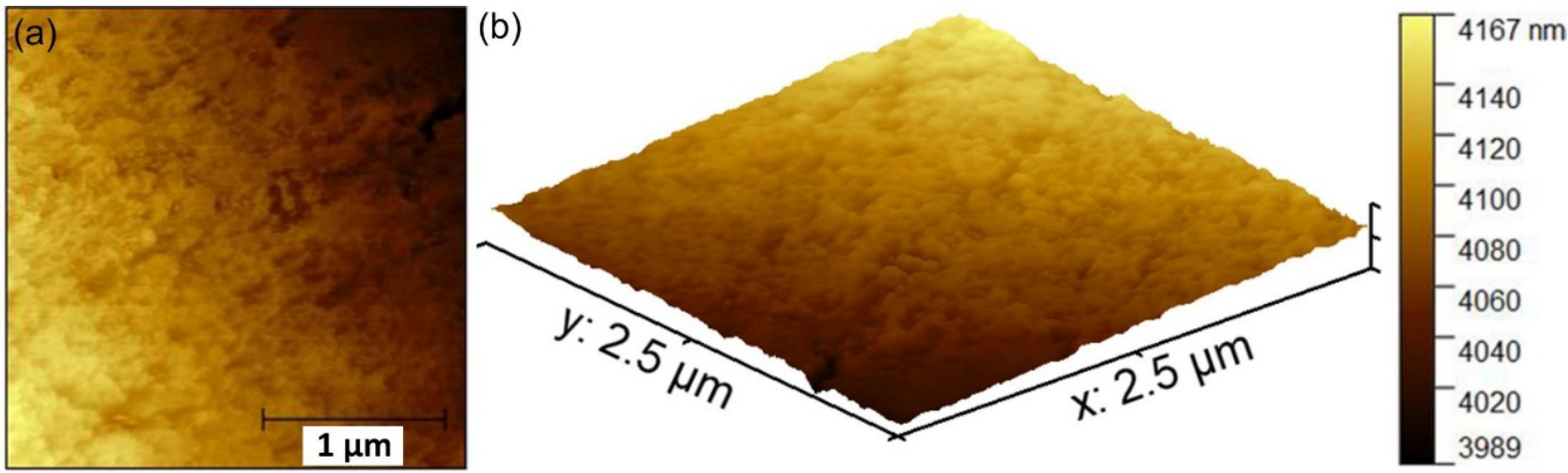

Figure 7. 2D atomic force microscopy (AFM) topography of NBrHAp coatings (a) and 3D representation of the NBrHAp coatings (b) surface collected on an area of $2.5 \times 2.5 \mu \mathrm{m}^{2}$.

The optical micrographs (2D and 3D representation) specific to the $\mathrm{N}$ and $\mathrm{Br}$ co-doped HAp thin films surface are depicted in Figure 8.
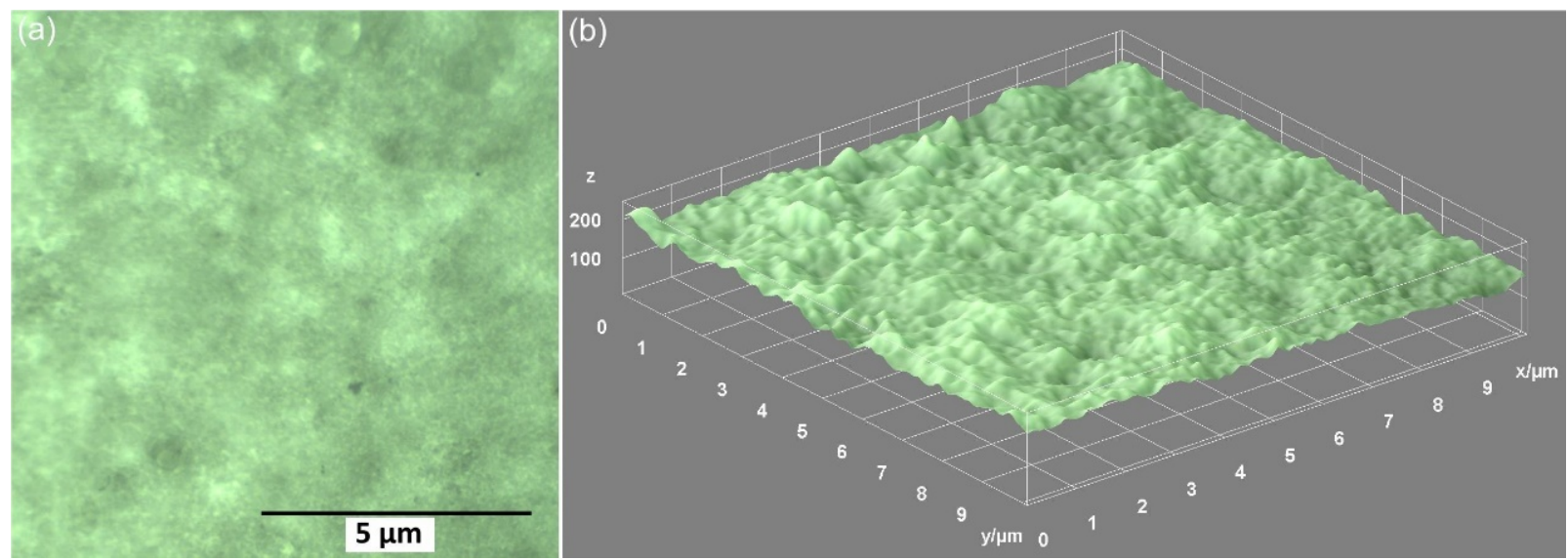

Figure 8. 2D (a) and 3D representation (b) of optical micrographs obtained on $\mathrm{N}$ and Br co-doped HAp thin films (10× magnification).

The 2D optical micrographs highlight that the studied samples exhibit a smooth surface topography with no visible cracks or corrugation. Furthermore, the 3D representation of the 2D optical micrographs characteristic of $\mathrm{N}$ and $\mathrm{Br}$ co-doped HAp thin films deposited on the glass substrate was in good agreement with the 3D representation of the SEM images showing a smooth surface and lack of irregularities. These results were consistent with previous studies conducted by R.A. Ismail and coworkers [48].

The 2D metallographic images together with their 3D reconstruction obtained on $\mathrm{N}$ and $\mathrm{Br}$ co-doped HAp thin films deposited on the glass substrate at $10 \times$ magnification are presented in Figure 9. To obtain the 3D reconstruction of the metallographic images, ImageJ software was used [36].

The 2D metallographic images highlight the morphological characteristics of the surface of the studied layers. Therefore, the continuity, homogeneity and lack of surface defects were also confirmed by the results of metallographic microscopy studies. It can thus be inferred that all four microscopy techniques used to investigate the surface morphology/topography of $\mathrm{N}$ and $\mathrm{Br}$ co-doped HAp thin films confirmed their superior morphological properties.

The emergence of drug resistance is currently one of the biggest challenges for public health at a global level, threatening not only the treatment of infectious diseases, but also many medical interventions such as oncologic treatments, organ transplant, treatment of immunocompromised patients, general surgery, and implantology [25,49-57]. 


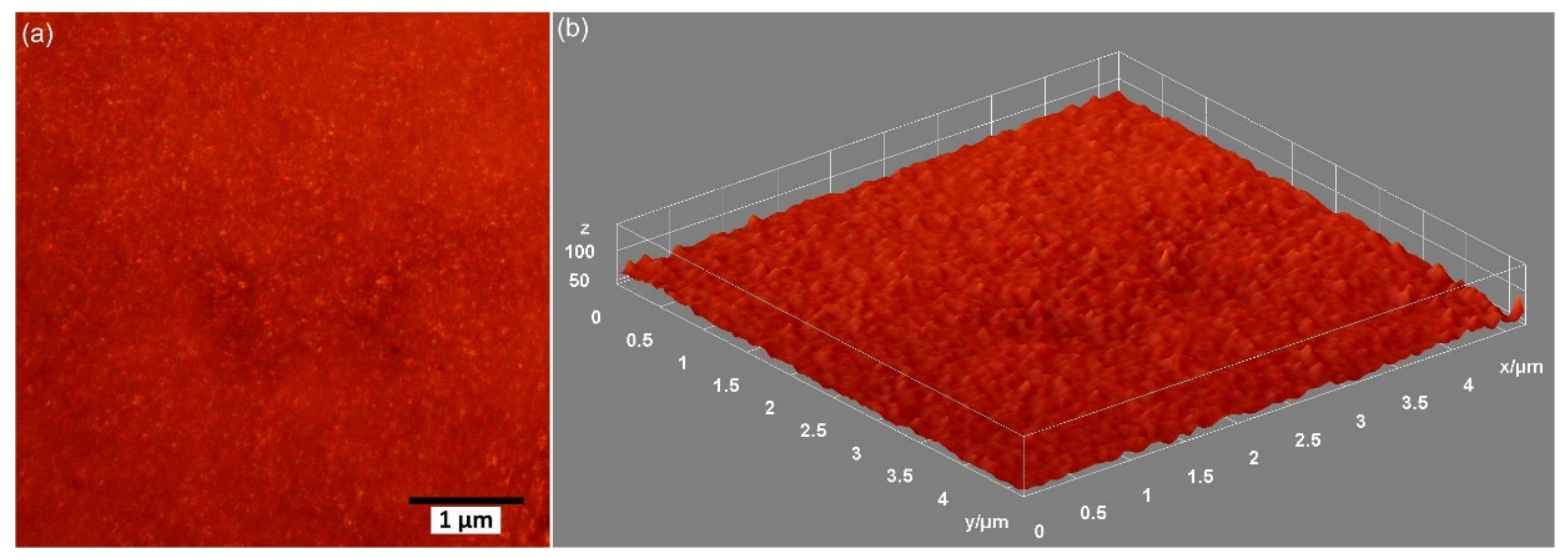

Figure 9. Metallographic images in 2D (a) and 3D representation (b) typical for $\mathrm{N}$ and Br co-doped HAp thin films deposited on the glass substrate.

In this context, the development of novel antimicrobial materials that could resist microbial colonization and/or exhibit antimicrobial properties is considered to be of great importance for the sustainable development of the health system worldwide.

Therefore, in this study, the in vitro antimicrobial activity of the NBrHAp suspensions and coatings was assessed using Gram-positive, Gram-negative and fungal microbial strains. Staphylococcus aureus is an infectious pathogen and has been recognized as being one of the most important bacteria responsible for severe morbidity and often fatal infections in humans [58-62]. Staphylococci are frequently found in hospitals, households, and are also present in the food industry and on different surfaces. Escherichia coli is often found in the environment, in many types of foods, and in the intestine of both people and animals. Infections with $E$. coli can be the cause of diseases such as diarrhea, urinary tract infections, respiratory illness and pneumonia, septicemia, meningitis, and other infections [63,64]. Last, but not least, Candida albicans is an opportunistic fungal pathogen responsible for superficial mucosal infections and life-threatening systemic candidiasis [23,65,66]. All three genera are important etiological agents of implant-associated infections and orthopedic infections. Staphylococcus aureus is the etiological agent of about $80 \%$ of implant-related infections, of which $34 \%$ are nosocomial [67]. Escherichia coli dominates the etiology of Gram-negative prosthetic joint-associated infections [68], while Candida albicans has been associated with orthopedic joint, hip or dental implants [69,70].

The incidence of these infections could, however, be underestimated since the microorganisms attached as a biofilm on prosthesis surfaces might change their phenotype, leading to false-negative culture results [71].

Biofilms are protected from both immune defense mechanisms and antibiotic and antifungal treatments by their extracellular polysaccharide matrix and many other mechanisms, and, therefore, preventing their formation on medical devices by obtaining new generation biomaterials with antimicrobial properties is more effective than treating them [72].

The antimicrobial activity of the NBrHAp suspensions and coatings was studied at different time intervals of incubation (24, 48 and $72 \mathrm{~h}$ ) by determining the colony forming units (CFU) inhibition for each tested microbial strain. The results of the in vitro antimicrobial assays are presented in Figure 10. The experiments were performed three times and the data was depicted as mean \pm SD. A statistical analysis was also performed with the aid of the ANOVA single factor algorithm. The statistical significance was considered at $p$-values obtained from the ANOVA algorithm less than 0.0001 [73]. The results of the in vitro antimicrobial assays revealed that both NBrHAp suspensions and coatings exhibited a good antimicrobial effect towards the Gram-positive, Gram-negative and fungal microbial strains even after $24 \mathrm{~h}$ of incubation with the suspensions and coatings, as indicated by the $\mathrm{CFU}$ values which were reduced significantly compared with the control culture $(\mathrm{C}+)$. The CFU decrease was evidenced for all tested samples and the inhibitory effect increased with the incubation time. Furthermore, the results suggested that antimicrobial activity 
was more pronounced in the case of suspensions than in the case of coatings, for all tested microbial strains at all tested time intervals. Although the NBrHAp suspensions and coatings showed an enhanced antimicrobial activity for all tested microbial strains, $C$. albicans was the most susceptible to both NBrHAp suspensions and coatings for all tested time intervals. Moreover, the data suggested that the antibacterial activity against $S$. aureus was slightly better compared with that against $E$. coli. The differences in the inhibitory activity exhibited by the NBrHAp suspensions and coatings against the tested strains are usually attributed to the different structures of these microorganisms. Additionally, the antimicrobial activity of NBrHAp (against tested microbial strains) was similar to that reported for silver-doped hydroxyapatite [74]. This study's results are in agreement with other existing studies $[64,75,76]$ that have demonstrated a better antibacterial activity against Gram-positive bacterial strains compared with Gram-negative ones due to the presence of an additional barrier represented by the outer cell membrane of the Gram-negative bacteria, which is mainly composed of lipopolysaccharides, lipoproteins, and phospholipids, that could easily trap positively charged ions or molecules and prevent their penetration into the cell and thus, reaching their molecular targets [23].

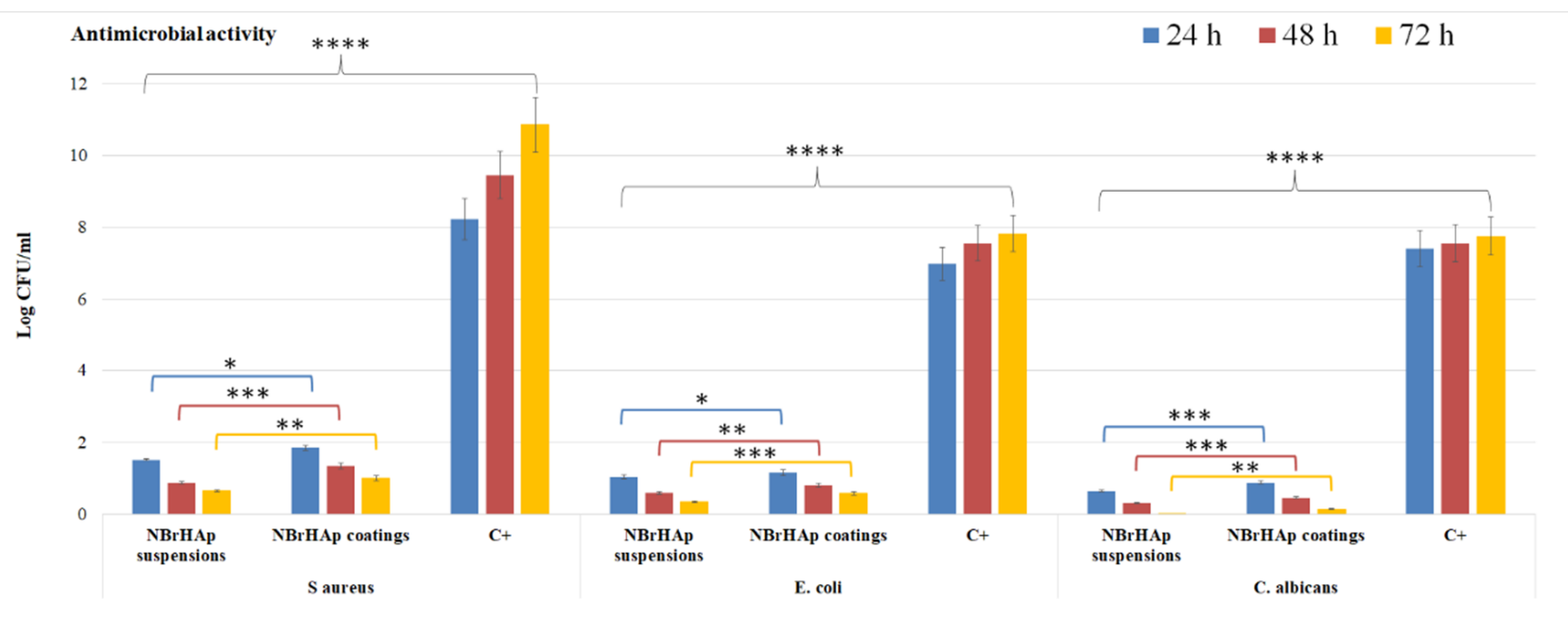

Figure 10. Graphic representation of the logarithmic values of colony forming units (CFU)/mL of S. aureus ATCC 25923, E. coli ATCC 25922, and C. albicans ATCC 10231 microbial strains after 24, 48 and $72 \mathrm{~h}$ of incubation with NBrHAp suspensions and coatings. The results are presented as means \pm standard error of the mean of 3 independent experiments. Statistical analysis was performed by ordinary one-way ANOVA and Tukey multiple comparisons. The $p$-values indicated are ${ }^{*} p \leq 0.003,{ }^{* *} p \leq 0.002,{ }^{* * *} p \leq 0.001,{ }^{* * * *} p \leq 0.0001$.

QACs are cationic surfactants (positively charged surface-active agents) commonly used as antiseptics and disinfectants [77-80]. Due to their positive charge, they can easily bind to the negatively charged surface of numerous microbes. It has been reported that their antimicrobial activity is also correlated with the length of the alkyl chain, the presence of the perfluorinated group and the number of cationic ammonium groups in the molecule [81]. The studies reported by Ahlstrom et al. [82] concluded that QACs having a C16 tail length more intensively affected the outer membrane of Gram-negative bacteria than QACs with shorter-chain compounds. In addition, the studies presented by Hamilton et al. [83] reported that QACs, due to their large adsorption to the bacterial membrane, could cause membrane damage, impairment of the protein activity and cell content leakage $[83,84]$. In addition, it has also been reported that QACs affect the bacterial DNA and block multiplication [85]. Furthermore, the bactericidal activity of these compounds has also been attributed to the inactivation of the energetic metabolism of enzymes, or to their denaturing effect on the essential cell proteins [79-85]. The bactericidal/microbicidal effects of QACs are attributed to their ability to disrupt intermolecular interactions. Moreover, besides their microbicidal effects, QACs can be responsible for the modification of the properties of 
abiotic surfaces of microbial cells $[86,87]$. Nonetheless, there is no evidence of them being effective against endospores [79]. Even though complex understanding of the mechanism of antimicrobial activity of different compounds is still scarce, the proposed mechanisms discussed above are generally supported by the present literature [88]. In the light of current knowledge, the antimicrobial activity of cationic surfactants could be described as a sequence of events, i.e., first they are attracted by the negatively charged surface of the microbial cells, then they are adsorbed via the hydrophobic headgroup, after that they interact with the lipids and proteins from the membrane penetrating the cell, and then interact with the intracellular components of the microbial cell causing disruptions and leading to cell death [88-91]. The most widely used QAC for biomedical applications is CTAB [92,93], which is why it was chosen for this study.

Even though the antimicrobial activity of surfactants is expected to be correlated to PM damage [94-97], in their study, Yu et al. [23] demonstrated that at a concentration ranging from 0 to $0.5 \mathrm{ppm}, \mathrm{CTAB}$ had no impact on PM integrity and also reported that CTAB surfactant had a stronger inhibitory effect on the hyphal development than on the growth of the C. albicans fungal cells. On the other hand, Nakata et al. [18] reported that CTAB contributed to the inhibition of the activity of antioxidant enzymes causing an intracellular accumulation of superoxide and hydrogen peroxide, revealing that reactive oxygen species (ROS) could be correlated with the antimicrobial activity of these surfactants. Furthermore, the antimicrobial properties of materials and their mechanism of action against microbial cells is also influenced by a series of factors, such as the type of the microbial cells, the type of the antimicrobial agent (powders, dispersion, nanoparticles, coatings, etc.) and other parameters such as temperature, $\mathrm{pH}$, slow or fast action. All these factors and probably many more are to be considered when describing the possible antimicrobial mechanism of a material. The interaction between a dispersion of particles and a coating with the microbial cell are different, and therefore the mechanism involved may differ. The synergistic interactions that appear between the substrate and coating can improve or generate new properties of the materials and/or substrate [97]. Unfortunately, until now, the scientific community's understanding of the interaction between microbial cells and surfaces is still scarce $[96,97]$. We consider that the mechanisms responsible for the antimicrobial activity of both dispersions based on $\mathrm{N}$ and Br co-doped HAp and their corresponding coatings have the best chance to be similar to those detailed above, as the same compounds are involved.

\section{Conclusions}

$\mathrm{N}$ and $\mathrm{Br}$ co-doped hydroxyapatite were obtained for the first time by an adapted coprecipitation method to produce NBrHAp composite thin films by spin-coating technique. The XRD studies revealed that the crystalline phase of obtained NBrHAp powders kept the single phase of pure HAp. The presence of $\mathrm{N}$ and $\mathrm{Br}$ was highlighted in the EDS spectrum of NBrHAp composite thin films. The XPS studies of NBrHAp composite thin films revealed the presence of $\mathrm{N}$ and $\mathrm{Br}$ in the HAp structure. The results of the FTIR studies confirmed the presence of the typical functional groups of hydroxyapatite and CTAB in the studied samples. Moreover, all microscopy techniques (SEM, AFM, optical and metallographic microscopies) used to investigate the surface morphology/topography of $\mathrm{N}$ and $\mathrm{Br}$ co-doped HAp thin films suggested that spin coating was an appropriate method of obtaining layers (thin films) with superior morphological properties. The results of the in vitro antimicrobial activity of the NBrHAp suspensions and coatings against reference microbial strains S. aureus ATCC 25923, E. coli ATCC 25922, and C. albicans ATCC 10231 revealed their good antimicrobial activity, making them suitable candidates to obtain new implant coatings resistant to biofilm development.

Author Contributions: Conceptualization, D.P., S.L.I., M.V.P. and M.M.-H.; methodology, D.P., S.L.I., M.V.P., C.S.C., C.M.C. and M.M.-H.; software, M.V.P.; validation, D.P., C.S.C., S.L.I., M.M.-H., C.M.C., C.S.C., C.C.N., M.P. and M.L.B.; formal analysis, D.P., S.L.I. and C.S.C.; investigation, S.L.I., D.P., C.S.C., M.M.-H., M.L.B., C.M.C., C.C.N. and M.P.; resources, D.P., S.L.I., M.V.P., M.M.-H. and C.M.C.; 
data curation, D.P., S.L.I., C.S.C., M.M.-H. and C.M.C.; writing-original draft preparation, D.P., S.L.I., C.S.C. and M.V.P.; writing-review and editing, D.P., S.L.I., C.S.C., M.M.-H. and C.M.C.; visualization, S.L.I., D.P., M.M.-H., C.S.C., M.L.B., M.P. and C.M.C.; supervision, D.P., S.L.I. and C.M.C.; project administration, D.P. and S.L.I.; funding acquisition, D.P. All authors have read and agreed to the published version of the manuscript.

Funding: This work was supported by the Romanian Ministry of Research and Innovation through the project PN-III-P2-2.1-PED-2019-0868 contract number 467PED/2020; project PN-III-P2-2.1-PED2019-1375 contract number 331/PED/2020 and Core Program PN19-030101 (contract 21N/2019) and CNFIS-FDI-2021-0405.

Institutional Review Board Statement: Not applicable.

Informed Consent Statement: Not applicable.

Data Availability Statement: Not applicable.

Conflicts of Interest: The authors declare no conflict of interest. The funders had no role in the design of the study; in the collection, analyses, or interpretation of data; in the writing of the manuscript, or in the decision to publish the results.

\section{References}

1. Arami, H.; Mohajerani, M.; Mazloumi, M.; Khalifehzadeh, R.; Lak, A.; Sadrnezhaad, S.K. Rapid formation of hydroxyapatite nanostrips via microwave irradiation. J. Alloys Compd. 2009, 469, 391-394. [CrossRef]

2. Pu'ad, N.M.; Haq, R.A.; Noh, H.M.; Abdullah, H.Z.; Idris, M.I.; Lee, T.C. Synthesis method of hydroxyapatite: A review. Mater. Today Proc. 2020, 29, 233-239. [CrossRef]

3. Tari, N.E.; Motlagh, M.M.K.; Sohrabi, B. Synthesis of hydroxyapatite particles in catanionic mixed surfactants template. Mater. Chem. Phys. 2011, 131, 132-135. [CrossRef]

4. Predoi, S.-A.; Ciobanu, C.S.; Motelica-Heino, M.; Chifiriuc, M.C.; Badea, M.L.; Iconaru, S.L. Preparation of Porous Hydroxyapatite Using Cetyl Trimethyl Ammonium Bromide as Surfactant for the Removal of Lead Ions from Aquatic Solutions. Polymers 2021, 13, 1617. [CrossRef]

5. Namiki, R.; Suyama, T.; Izawa, C.; Ikeda-Fukazawa, T.; Honda, M.; Watanabe, T.; Aizawa, M. Chemical State of Nitrogen in Nitrogen-Doped Hydroxyapatite Ceramics with Enhanced Bioactivity. Key Eng. Mater. 2016, 720, 215-218. [CrossRef]

6. Pramanik, S.; Agarwal, A.K.; Rai, K.N.; Garg, A. Development of high strength hydroxyapatite by solid-state-sintering process. Ceram. Int. 2007, 33, 419-426. [CrossRef]

7. Fathi, M.H.; Mohammadi Zahrani, E. Mechanical alloying synthesis and bioactivity evaluation of nanocrystalline fluoridated hydroxyapatite. J. Cryst. Growth 2009, 311, 1392-1403. [CrossRef]

8. Ciobanu, C.S.; Iconaru, S.L.; Massuyeau, F.; Constantin, L.V.; Costescu, A.; Predoi, D. Synthesis, structure, and luminescent properties of europium-doped hydroxyapatite nanocrystalline powders. J. Nanomater. 2012, 2012, 61. [CrossRef]

9. Fihri, A.; Len, C.; Varma, R.S.; Solhy, A. Hydroxyapatite: A review of syntheses, structure and applications in heterogeneous catalysis. Coord. Chem. Rev. 2017, 347, 48-76. [CrossRef]

10. Liu, D.M.; Troczynski, T.; Tseng, W.J. Water-based sol-gel synthesis of hydroxyapatite: Process development. Biomaterials 2001, 22, 1721-1730. [CrossRef]

11. Widiyastuti, W.; Setiawan, A.; Winardi, S.; Nurtono, T.; Setyawan, H. Particle formation of hydroxyapatite precursor containing two components in a spray pyrolysis process. Front. Chem. Sci. Eng. 2014, 8, 104-113. [CrossRef]

12. Safavi, M.S.; Walsh, F.C.; Surmeneva, M.A.; Surmenev, R.A.; Khalil-Allafi, J. Electrodeposited hydroxyapatite-based biocoatings: Recent progress and future challenges. Coatings 2021, 11, 110. [CrossRef]

13. Arcos, D.; Vallet-Regí, M. Substituted hydroxyapatite coatings of bone implants. J. Mater. Chem. B 2020, 8, 1781-1800. [CrossRef]

14. What Chemical Elements are Found in the Human Body? Available online: news-medical.net (accessed on 20 October 2021).

15. Izutani, N.; Imazato, S.; Nakajo, K.; Takahashi, N.; Takahashi, Y.; Ebisu, S.; Russell, R.R.B. Effects of the antibacterial monomer 12-methacryloyloxydodecylpyridinium bromide (MDPB) on bacterial viability and metabolism. Eur. J. Oral Sci. 2011, 119, 175-181. [CrossRef] [PubMed]

16. Galarraga-Vinueza, M.E.; Passoni, B.; Benfatti, C.A.M.; Mesquita-Guimarães, J.; Henriques, B.; Magini, R.S.; Fredel, M.C.; Meerbeek, B.V.; Teughels, W.; Souza, J.C.M. Inhibition of multi-species oral biofilm by bromide doped bioactive glass. J. Biomed. Mater. Res. A 2017, 105, 1994-2003. [CrossRef] [PubMed]

17. Bagherzadeh, R.; Montazer, M.; Latifi, M.; Sheikhzadeh, M.; Sattari, M. Evaluation of comfort properties of polyester knitted spacer fabrics finished with water repellent and antimicrobial agents. Fibers Polym. 2007, 8, 386-392. [CrossRef]

18. Nakata, K.; Tsuchido, T.; Matsumura, Y. Antimicrobial cationic surfactant, cetyltrimethylammonium bromide, induces superoxide stress in Escherichia coli cells. J. Appl. Microbiol. 2011, 110, 568-579. [CrossRef] 
19. Criado, A.; Lavela, P.; Ortiz, G.F.; Tirado, J.L.; Gzouli, S.; Edfouf, Z.; Pérez-Vicente, C. CTAB-Assisted Synthesis of C@Na3V2(PO4)2F3 With Optimized Morphology for Application as Cathode Material for Na-Ion Batteries. Front. Phys. 2019, 7, 207. [CrossRef]

20. Smith, D.K.; Korgel, B.A. The importance of the CTAB surfactant on the colloidal seed-mediated synthesis of gold nanorods. Langmuir 2008, 24, 644-649. [CrossRef]

21. Cao, D.; Jin, X.; Gan, L.; Wang, T.; Chen, Z. Removal of phosphate using iron oxide nanoparticles synthesized by eucalyptus leaf extract in the presence of CTAB surfactant. Chemosphere 2016, 159, 23-31. [CrossRef]

22. Clarke, J.D. Cetyltrimethyl Ammonium Bromide (CTAB) DNA Miniprep for Plant DNA Isolation. Cold Spring Harb. Protoc. 2009, 4, 1-2. [CrossRef] [PubMed]

23. Yu, Q.; Zhang, B.; Ma, F.; Jia, C.; Xiao, C.; Zhang, B.; Xing, L.; Li, M. Novel mechanisms of surfactants against Candida albicans growth and morphogenesis. Chem. Biol. Interact. 2015, 227, 1-6. [CrossRef]

24. Abduraimova, A.; Molkenova, A.; Duisembekova, A.; Mulikova, T.; Kanayeva, D.; Atabaev, T.S. Cetyltrimethylammonium Bromide (CTAB)-Loaded SiO2-Ag Mesoporous Nanocomposite as an Efficient Antibacterial Agent. Nanomaterials 2021, 11, 477. [CrossRef] [PubMed]

25. McDonnell, G.E. Antisepsis, Disinfection, and Sterilization; ASM Press: Washington, DC, USA, 2007.

26. Oliveira, W.F.; Silva, P.M.S.; Silva, R.C.S.; Silva, G.M.M.; Machado, G.; Coelho, L.C.B.B.; Correia, M.T.S. Staphylococcus aureus and Staphylococcus epidermidis infections on implants. J. Hosp. Infect. 2018, 98, 111-117. [CrossRef]

27. Crémet, L.; Broquet, A.; Brulin, B.; Jacqueline, C.; Dauvergne, S.; Brion, R.; Asehnoune, K.; Corvec, S.; Heymann, D.; Caroff, N. Pathogenic potential of Escherichia coli clinical strains from orthopedic implant infections towards human osteoblastic cells. Pathog. Dis. 2015, 73, ftv065. [CrossRef]

28. Passarelli, P.C.; De Leonardis, M.; Piccirillo, G.B.; Desantis, V.; Papa, R.; Rella, E.; Mastandrea Bonaviri, G.N.; Papi, P.; Pompa, G.; Pasquantonio, G.; et al. The Effectiveness of Chlorhexidine and Air Polishing System in the Treatment of Candida albicans Infected Dental Implants: An Experimental In Vitro Study. Antibiotics 2020, 9, 179. [CrossRef]

29. Ciobanu, C.S.; Massuyeau, F.; Constantin, L.V.; Predoi, D. Structural and physical properties of antibacterial Ag-doped nanohydroxyapatite synthesized at 100 C. Nanoscale Res. Lett. 2011, 6, 1-8. [CrossRef]

30. Predoi, D.; Iconaru, S.L.; Predoi, M.V. Dextran-coated zinc-doped hydroxyapatite for biomedical applications. Polymers 2019, 11, 886. [CrossRef] [PubMed]

31. Predoi, D.; Iconaru, S.L.; Predoi, M.V. Bioceramic Layers with Antifungal Properties. Coatings 2018, 8, 276. [CrossRef]

32. Danilchenko, S.N.; Kukharenko, O.G.; Moseke, C.; Protsenko, I.Y.; Sukhodub, L.F.; Sulkio-Cleff, B. Determination of the bone mineral crystallite size and lattice strain from diffraction line broadening. Cryst. Res. Technol. 2002, 37, 1234-1240. [CrossRef]

33. Barrett, C.S.; Cohen, J.B.; FaberJ, J.; Jenkins, R.; Leyden, D.E.; Russ, J.C.; Predecki, P.K. Advances in X-ray Analysis; Plenum Press: New York, NY, USA, 1986; Volume 29.

34. Visser, J.W. A fully automatic program for finding the unit cell from powder data. J. Appl. Cryst. 1969, 2, 89-95. [CrossRef]

35. Predoi, D.; Iconaru, S.L.; Deniaud, A.; Chevallet, M.; Michaud-Soret, I.; Buton, N.; Prodan, A.M. Textural, Structural and Biological Evaluation of Hydroxyapatite Doped with Zinc at Low Concentrations. Materials 2017, 10, 229. [CrossRef]

36. ImageJ Website. Available online: http://imagej.nih.gov/ij (accessed on 1 October 2021).

37. Gwyddion. Available online: http://gwyddion.net/ (accessed on 1 October 2021).

38. Predoi, D.; Iconaru, S.L.; Predoi, M.V.; Motelica-Heino, M.; Buton, N.; Megier, C. Obtaining and Characterizing Thin Layers of Magnesium Doped Hydroxyapatite by Dip Coating Procedure. Coatings 2020, 10, 510. [CrossRef]

39. Predoi, D.; Iconaru, S.L.; Predoi, M.V. Fabrication of Silver- and Zinc-Doped Hydroxyapatite Coatings for Enhancing Antimicrobial Effect. Coatings 2020, 10, 905. [CrossRef]

40. Iconaru, S.L.; Prodan, A.M.; Turculet, C.S.; Beuran, M.; Ghita, R.V.; Costescu, A.; Groza, A.; Chifiriuc, M.C.; Chapon, P.; Gaiaschi, S.; et al. Enamel Based Composite Layers Deposited on Titanium Substrate with Antifungal Activity. J. Spectrosc. 2016, $2016,4361051$. [CrossRef]

41. Bodycomb. Available online: http://www.horiba.com/us/particle (accessed on 17 November 2021).

42. Fissan, H.; Ristig, S.; Kaminski, H.; Asbacha, C.; Epple, M. Comparison of different characterization methods for nanoparticle dispersions before and after aerosolization. Anal. Methods 2014, 6, 7324. [CrossRef]

43. Zhao, J.; Dong, X.; Bian, M.; Zhao, J.; Zhang, Y.; Sun, Y.; Chen, J.H.; Wang, X.H. Solution combustion method for synthesis of nanostructured hydroxyapatite, fluorapatite and chlorapatite. Appl. Surf. Sci. 2014, 314, 1026-1033. [CrossRef]

44. Rusu, V.M.; Ng, C.H.; Wilke, M.; Tiersch, B.; Fratzl, P.; Peter, M.G. Size controlled hydroxyapatite nanoparticles as self-organised organic-inorganic composite materials. Biomaterials 2005, 26, 5414-5426. [CrossRef] [PubMed]

45. Bokuniaeva, A.O.; Vorokh, A.S. Estimation of particle size using the Debye equation and the Scherrer formula for polyphasic $\mathrm{TiO}_{2}$ powder. J. Phys. Conf. Ser. 2019, 1410, 012057. [CrossRef]

46. Klug, H.P.; Alexander, L.E. X-ray Diffraction Procedures for Polycrystallite and Amorphous Materials, 2nd ed.; Wiley: New York, NY, USA, 1974.

47. Salarian, M.; Solati-Hashjin, M.; Shafiei, S.S.; Goudarzi, A.; Salarian, R.; Nemati, A. Surfactant-assisted synthesis and characterization of hydroxyapatite nanorods under hydrothermal conditions. Mater. Sci.-Pol. 2009, 1, 27.

48. Kaneko, N.; Suzuki, Y.; Umeda, R.; Namiki, R.; Izawa, C.; Fukazawa, T.I.; Honda, M.; Takei, T.; Watanabe, T.; Aizawa, M. Development of nitrogen-doped hydroxyapatite ceramics. J. Asian Ceram. Soc. 2020, 8, 130-137. [CrossRef] 
49. Ismail, R.A.; Salim, E.T.; Hamoudi, W.K. Characterization of nanostructured hydroxyapatite prepared by Nd: YAG laser deposition. Mater. Sci. Eng. C 2013, 33, 47-52. [CrossRef]

50. Available online: https://www.who.int/antimicrobial-resistance/publications/surveillancereport/en/ (accessed on 15 October 2021).

51. Ventola, C.L. The antibiotic resistance crisis: Part 1: Causes and threats. Pharm. Ther. 2015, 40, $277-283$.

52. World Health Organization. Global Action Plan on Antimicrobial Resistance. 2021. Available online: cdc.gov/drugresistance/ biggest-threats.html (accessed on 25 February 2021).

53. de Kraker, M.E.; Stewardson, A.J.; Harbarth, S. Will 10 million people die a year due to antimicrobial resistance by 2050? PLoS Med. 2016, 13, e1002184. [CrossRef] [PubMed]

54. Cohen, M.E.; Salmasian, H.; Li, J.; Liu, J.; Zachariah, P.; Wright, J.D.; Freedberg, D.E. Surgical antibiotic prophylaxis and risk for postoperative antibiotic-resistant infections. J. Am. Coll. Surg. 2017, 225, 631-638.e3. [CrossRef]

55. DeNegre, A.A.; Ndeffo Mbah, M.L.; Myers, K.; Fefferman, N.H. Emergence of antibiotic resistance in immunocompromised host populations: A case study of emerging antibiotic resistant tuberculosis in AIDS patients. PLoS ONE 2019, 14, e0212969. [CrossRef]

56. Bartoletti, M.; Giannella, M.; Tedeschi, S.; Viale, P. Multidrug-resistant bacterial infections in solid organ transplant candidates and recipients. Infect. Dis. Clin. N. Am. 2018, 32, 551-580. [CrossRef]

57. Ravi, S.; Zhu, M.; Luey, C.; Young, S.W. Antibiotic resistance in early periprosthetic joint infection. ANZ J. Surg. 2016, 86, 1014-1018. [CrossRef]

58. Ma, J.; Jemal, A.; Fedewa, S.A.; Islami, F.; Lichtenfeld, J.L.; Wender, R.C.; Cullen, K.J.; Brawley, O.W. The American Cancer Society 2035 challenge goal on cancer mortality reduction. CA Cancer J. Clin. 2019, 69, 351-362. [CrossRef] [PubMed]

59. Tian, Y.; Sun, P.; Wu, H.; Bai, N.; Wang, R.; Zhu, W.; Zhang, J.; Liu, F. Inactivation of Staphylo coccus aureus and Enterococcus faecalis by a direct-current, cold atmospheric-pressure air plasma microjet. J. Biomed. Mater. Res. 2010, 24, 264-269. [CrossRef]

60. Gehanno, J.F.; Louvel, A.; Nouvellon, M.; Caillard, J.-F.; Pestel-caron, M. Aerial dispersal of meticillin-resistant Staphylococcus aureus in hospital rooms by infected or colonised patients. J. Hosp. Infect. 2009, 71, 256-262. [CrossRef]

61. Gopal, J.; Narayana, J.L.; Wu, H.-F. $\mathrm{TiO}_{2}$ nanoparticle assisted mass spectrometry as biosensor of Staphylococcus aureus, key pathogen in nosocomial infections from air, skin surface and human nasal passage. Biosens. Bioelectron. 2011, 27, 201-206. [CrossRef] [PubMed]

62. Farias, E.A.O.; Dionisio, N.A.; Quelemes, P.V.; Leal, S.H.; Matos, J.M.E.; Silva Filho, E.C.; Bechtold, I.H.; Leite, J.R.S.; Eiras, C. Development and characterization of multilayer films of polyaniline, titanium dioxide and CTAB for potential antimicrobial applications. Mater. Sci. Eng. C 2014, 35, 449-454. [CrossRef]

63. Gheorghe, I.; Tatu, A.L.; Lupu, I.; Thamer, O.; Cotar, A.I.; Pircalabioru, G.G.; Popa, M.; Cristea, V.C.; Lazar, V.; Chifiriuc, M.C. Molecular characterization of virulence and resistance features in Staphylococcus aureus clinical strains isolated from cutaneous lesions in patients with drug adverse reactions. Rom. Biotechnol. Lett. 2017, 22, 12321-12327.

64. Available online: https://www.cdc.gov/ecoli/general/index.html (accessed on 24 October 2021).

65. Salim, M.M.; Malek, N.A.N.N.; Ramli, N.I.A.; Hanim, S.A.M.; Hamdan, S. Antibacterial activity of CTAB-modified zeolite NaY with different CTAB loading. Malays. J. Fund. Appl. Sci. 2014, 10. [CrossRef]

66. Vincent, J.L.; Anaissie, E.; Bruining, H.; Demajo, W.; El-Ebiary, M.; Haber, J.; Hiramatsu, Y.; Nitenberg, G.; Nyström, P.O.; Pittet, D.; et al. Epidemiology, diagnosis and treatment of systemic Candida infection in surgical patients under intensive care. Intensive Care Med. 1998, 24, 206-216. [CrossRef] [PubMed]

67. Klepser, M.E. Candida resistance and its clinical relevance. Pharmacotherapy 2006, 26, 68-75. [CrossRef]

68. Campoccia, D.; Montanaro, L.; Arciola, C.R. The significance of infection related to orthopedic devices and issues of antibiotic resistance. Biomaterials 2006, 27, 2331-2339. [CrossRef] [PubMed]

69. Rodríguez-Pardo, D.; Pigrau, C.; Lora-Tamayo, J.; Soriano, A.; del Toro, M.D.; Cobo, J.; Palomino, J.; Euba, G.; Riera, M.; Sánchez-Somolinos, M.; et al. Gram-negative prosthetic joint infection: Outcome of a debridement, antibiotics and implant retention approach. A large multicentre study. Clin. Microbiol. Infect. 2014, 20, O911-O919. [CrossRef]

70. García-Oltra, E.; García-Ramiro, S.; Martínez, J.C.; Tibau, R.; Bori, G.; Bosch, J.; Mensa, J.; Soriano, A. Prosthetic joint infection by Candida spp. Rev. Esp. Quimioter. 2011, 24, 37-41.

71. Kucharíková, S.; Gerits, E.; De Brucker, K.; Braem, A.; Ceh, K.; Majdič, G.; Španič, T.; Pogorevc, E.; Verstraeten, N.; Tournu, H.; et al. Covalent immobilization of antimicrobial agents on titanium prevents Staphylococcus aureus and Candida albicans colonization and biofilm formation. J. Antimicrob. Chemother. 2016, 71, 936-945. [CrossRef] [PubMed]

72. Sendi, P.; Frei, R.; Maurer, T.B.; Trampuz, A.; Zimmerli, W.; Graber, P. Escherichia coli variants in periprosthetic joint infection: Diagnostic challenges with sessile bacteria and sonication. J. Clin. Microbiol. 2010, 48, 1720-1725. [CrossRef]

73. Pircalabioru, G.G.; Chifiriuc, M.C. Nanoparticulate drug-delivery systems for fighting microbial biofilms: From bench to bedside. Future Microbiol. 2020, 15, 679-698. [CrossRef]

74. Lorowitz, W.; Saxton, E.; Sondossi, M.; Nakaoka, K. Integrating statistics with a microbiology laboratory activity. J. Microbiol. Biol. Educ. 2005, 6, 14-19. [CrossRef]

75. Ivanova, A.; Surmeneva, M.A.; Grubova, I.Y.; Sharonova, A.A.; Pichugin, V.F.; Chaikina, M.V.; Buck, V.; Prymak, O.; Epple, M.; Surmenev, R.A. Influence of the substrate bias on the stoichiometry and structure of RF-magnetron sputter-deposited silvercontaining calcium phosphate coatings. Materwiss. Werksttech. 2013, 44, 218-225. [CrossRef] 
76. Liu, J.; Li, S.; Fang, Y.; Zhu, Z. Boosting antibacterial activity with mesoporous silica nanoparticles supported silver nanoclusters. J. Colloid Interface Sci. 2019, 555, 470-479. [CrossRef]

77. Huang, R.S.; Hou, B.F.; Li, H.T.; Fu, X.C.; Xie, C.G. Preparation of silver nanoparticles supported mesoporous silica microspheres with perpendicularly aligned mesopore channels and their antibacterial activities. RSC Adv. 2015, 5, 61184-61190. [CrossRef]

78. McDonnell, G.; Russell, A.D. Antiseptics and disinfectants: Activity, action, and resistance. Clin. Microbiol. Rev. 1999, 12, 147-179. [CrossRef]

79. Chauret, C.P. Sanitization. In Encyclopedia of Food Microbiology, 2nd ed.; Robinson, R.K., Ed.; Academic Press: Cambridge, MA, USA, 2014.

80. McKeen, L. Introduction to Food Irradiation and Medical Sterilization. In The Effect of Sterilization on Plastics and Elastomers; William Andrew: Norwich, NY, USA, 2012; pp. 1-40. [CrossRef]

81. Nayak, R.; Padhye, R. Antimicrobial finishes for textiles. In Functional Finishes for Textiles; Paul, R., Ed.; Woodhead Publishing: Sawston, UK, 2015.

82. Gilbert, P.; Moore, L.E. Cationic antiseptics: Diversity of action under a common epithet. J. Appl. Microbiol. 2005, 99, 703-715. [CrossRef] [PubMed]

83. Ahlstrom, B.; Thompson, R.A.; Edebo, L. The effect of hydrocarbon chain length, $\mathrm{pH}$ and temperature on the binding and bactericidal effect of amphiphilic betaine esters on Salmonella typhimurium. APMIS 1999, 107, 318-324. [CrossRef]

84. Hamilton, W.A. The mechanism of the bacteriostatic action of tetrachlorosalicylanilide: A membrane-active antibacterial compound. J. Gen. Microbiol. 1968, 50, 441-458. [CrossRef]

85. Ioannou, C.J.; Hanlon, G.W.; Denyer, S.P. Action of disinfectant quaternary ammonium compounds against Staphylococcus aureus. Antimicrob. Agents Chemother. 2007, 51, 296-306. [CrossRef]

86. Marini, M.; Bondi, M.; Iseppi, R.; Toselli, M.; Pilati, F. Preparation and antibacterial activity of hybrid materials containing quaternary ammonium salts via sol-gel process. Eur. Polym. J. 2007, 43, 3621-3628. [CrossRef]

87. Simoes, M.; Pereira, M.O.; Vieira, M.J. Effect of mechanical stress on biofilms challenged by different c chemicals. Water Res. 2005, 39, 5142-5152. [CrossRef]

88. Araújo, P.A.; Lemos, M.; Mergulhão, F.; Melo, L.; Simões, M. The influence of interfering substances on the antimicrobial activity of selected quaternary ammonium compounds. Int. J. Food Sci. 2013, 2013, 237581. [CrossRef] [PubMed]

89. Gerba, C.P. Quaternary Ammonium Biocides: Efficacy in Application. Appl. Environ. Microbiol. 2014, 81, 464-469. [CrossRef]

90. Paulus, W. Directory of Microbicides for the Protection of Materials-A Handbook; Springer: London, UK, 1993.

91. Salton, M.R.J. Lytic agents, cell permeability, and monolayer penetrability. J. Gen. Physiol. 1968, 52, 227-252. [CrossRef] [PubMed]

92. Ferreira, C.; Pereira, A.M.; Pereira, M.C.; Melo, L.F.; Simões, M. Physiological changes induced by the quaternary ammonium compound benzyldimethyldodecylammonium chloride on Pseudomonas fluorescens. J. Antimicrob. Chemother. 2011, 66, 1036-1043. [CrossRef]

93. Sands, J.A. Virucidal activity of cetyltrimethylammonium bromide (CTAB) below the critical micelle concentration. FEMS Microbiol. Lett. 1986, 36, 261-263. [CrossRef]

94. Chatain-Ly, M.H.; Moussaoui, S.; Rigobello, V.; Demarigny, Y.; Vera, A. Antiviral effect of cationic compounds on bacteriophages. Front. Microbiol. 2013, 4, 46. [CrossRef] [PubMed]

95. Hamouda, T.; Baker, J.R., Jr. Antimicrobial mechanism of action of surfactantlipid preparations in enteric Gram-negative bacilli. J. Appl. Microbiol. 2000, 89, 397-403. [CrossRef] [PubMed]

96. Chen, C.; Hu, J.; Zhang, S.; Zhou, P.; Zhao, X.; Xu, H.; Zhao, X.; Yaseen, M.; Lu, J.R. Molecular mechanisms of antibacterial and antitumor actions of designed surfactant-like peptides. Biomaterials 2012, 33, 592-603. [CrossRef] [PubMed]

97. Tuson, H.H.; Weibel, D.B. Bacteria-surface interactions. Soft Matter 2013, 9, 4368-4380. [CrossRef] [PubMed] 